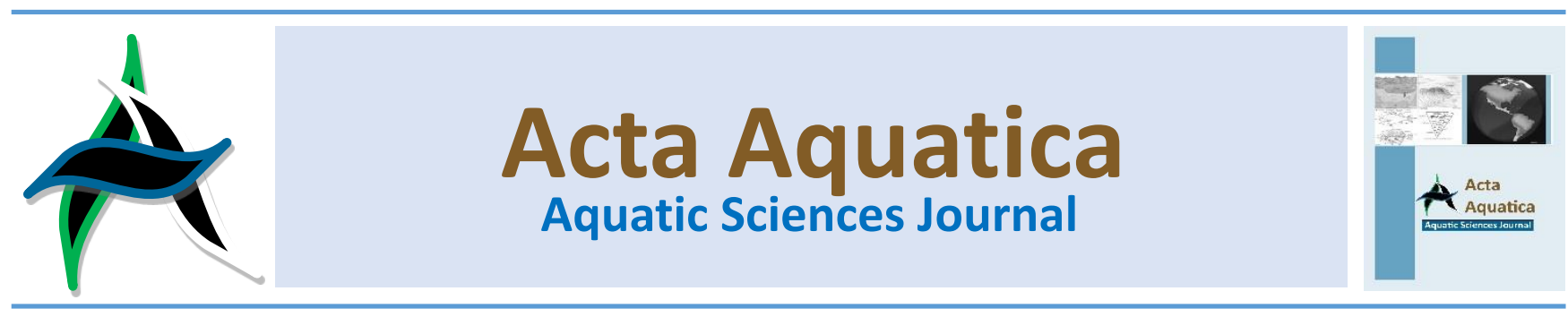

\title{
Studi pembesaran tiram (Crassostrea sp) melalui desain tata letak yang berbeda
}

\section{The study of culturing oyster (Crassostrea sp) through different layout design}

\author{
Zainura $^{\text {a } *}$, Rachmawati Rusydi ${ }^{a}$ dan Munawar Khalil ${ }^{a}$ \\ a Program Studi Budidaya Perairan, Fakultas Pertanian, Universitas Malikussaleh
}

\begin{abstract}
Abstrak
Tiram (Crassostrea $\mathrm{sp}$ ) merupakan salah satu bivalvial potensial yang dapat dikembangkan dalam rangka meningkatkan pendapatan ekonomi. Tata desain media budidaya tiram yang baik akan mempengaruhi pertumbuhan dan kelangsungan hidup tiram. Penelitian ini bertujuan untuk melihat tata desain media budidaya tiram yang baik sehingga mempengaruhi pertumbuhan dan kelangsungan hidup tiram. Penelitian ini dilaksanakan di Keramba Jaring Apung Loskala Lhokseumawe dan di Laboratorium Hatchery dan Teknologi Reulet Program Studi Budidaya Perairan Fakultas Pertanian Universitas Malikussaleh dari bulan Juni sampai Agustus 2015. Adapun perlakuannya yaitu metode peletakkan benih tiram secara rak (horizontal), gantung (vertikal) dan didasar perairan dengan substrak batuan. Adapun rancangan yang digunakan pada penelitian ini adalah Rancangan Acak Lengkap (RAL) dengan 3 ulangan dan 3 perlakuan dan dilanjutkan dengan uji Beda Nyata Terkecil (BNT) jika terdapat perbedaan. Parameter yang diamati adalah kelangsungan hidup, pertambahan panjang, lebar, ketebalan cangkang, pertambahan bobot dan kualitas air. Pertambahan bobot, lebar, panjang, dan ketebalan cangkang tertinggi terdapat pada perlakuan $B$ yaitu dengan nilai rata-rata sebesar 42,95 gram, 1,331 mm, 1,487 mm, $1,843 \mathrm{~mm}$ dan pertambahan bobot, lebar, panjang, dan ketebalan cangkang terendah terdapat pada perlakuan $\mathrm{C}$ yaitu 0,00 gram dan $0,00 \mathrm{~mm}$. Rata-rata kelangsungan hidup yaitu $84 \%$ pada perlakuan A dan B, $0 \%$ pada perlakuan C. parameter kualitas air berada pada kisaran yang baik untuk pertumbuhan tiram dalam kisaran suhu $27-30^{\circ} \mathrm{C}, \mathrm{pH} 6,8-7,5$, dan DO 4,87,4 ppm.
\end{abstract}

Kata kunci: Tiram; Desain tata letak; Pertumbuhan; Kelulushidupan

\begin{abstract}
Oysters (Crassostrea sp) is one of the bivalves that is potential to be developed for improving the economic income. The good layout design for culturing oyster will affect its growth and survival. This study aimed to evaluate the layout design which was good for oyster cultivation affecting the growth and survival of oyster. This research was conducted at floating cage Loskala, Lhokseumawe and in Hatchery and Technology Laboratory, Aquaculture Department, Agriculture Faculty Malikussaleh University fwhich was held on June to August 2015. The treatments were to use rack method (horizontal), hanging (vertical) and bottom methods. Completely randomized design (CRD) was used as research design with three replication for three treatments. Then it was continued by LSD (Least Significant Difference) Test, if there was a difference. Parameters measured were survival length, width, thickness of the shell, weight and water quality. The highest weight, width, length, and thickness of shell were obtained in treatment $B$ which were 42,95 gram; 1,331 $\mathrm{mm}, 1,487 \mathrm{~mm}, 1,843 \mathrm{~mm}$. other wise, the lowest one were obtained in treatment $C$ which were 0 gram and $0 \mathrm{~mm}$. The survival rate of both treatment A and B was $89 \%$, which treatment $C$ was $0 \%$. water quality parameters were in good range for growth of oysters where as temperature $27-30^{\circ} \mathrm{C}, \mathrm{pH}$ 6,8 to 7,5 , and DO 4,8 to $7,4 \mathrm{ppm}$.
\end{abstract}

Keywords: Oyster; Layout design; Growth; Survival rate

\footnotetext{
* Korespondensi: Prodi Budidaya Perairan, Fakultas Pertanian, Universitas Malikussaleh. Kampus utama Reuleut, Kabupaten Aceh Utara, Aceh, Indonesia. Tel: +62-645-41373 Fax: +62-645-59089. e-mail: zainuranora17@yahoo.co.id
}

\section{Pendahuluan}

Tiram digunakan sebagai nama umum untuk sejumlah kelompok yang berbeda dari kerang moluska yang hidup di laut atau payau. Beberapa jenis tiram umumnya dikonsumsi seperti dimasak atau dimakan mentah oleh manusia sebagai makanan yang lezat. Tiram merupakan sumber nutrisi yang sangat baik karena di dalamnya mengandung zinc, zat besi, kalsium, 
selenium, serta vitamin A dan vitamin B. Tiram tersebar luas, beberapa jenis diantaranya telah berhasil dibudidayakan yang terdiri dari marga Ostrea yang berbentuk pipih dan marga Crassostrea yang berbentuk seperti piala. Tiram adalah anggota keluarga Ostreidae. Keluarga ini termasuk tiram dapat dimakan, yang terutama berasal dari genera Ostrea, Crassostrea, Ostreola, dan Saccostrea. Contohnya termasuk tiram belon, tiram timur, olympia tiram, tiram pasifik, dan tiram batu sydney (Meglitsch, 1972).

Tiram banyak dibudidayakan di negara-negara luar seperti Inggris, Amerika Serikat, Perancis, Malaysia dan masih banyak juga di negara-negara lain yang membudidayakan tiram tersebut. Akan tetapi, di Indonesia belum ada petani tambak yang membudidayakan tiram tersebut melainkan masyarakat yang berprofesi sebagai pencari tiram mengumpulkannya langsung dari alam. Hal ini dikarenakan penguasaan teknologi pembudidayaan tiram di Indonesia yang masih rendah.

Benih tiram dapat dikumpulkan secara langsung dari alam. Cara mendapatkannya adalah melalui pemasangan kolektor di tempat yang banyak di huni oleh induk-induk tiram dan pemasangannya pun dilakukan di saat musim spat berkembang agar tidak didahului menempelnya teritip, lumpur atau kotoran lainnya. Informasi tentang kawasan yang tepat dan media pembesaran yang baik untuk kehidupan tiram hingga saat ini masih sangat terbatas. Maka dari itu peneliti ingin mencoba melakukan penelitian tentang kedua hal tersebut. Penelitian tentang studi pembesaran tiram melalui desain tata letak yang berbeda menjadi penting sebagai informasi awal untuk para petani tambak yang ingin membudidayakan tiram tersebut.

Penelitian tentang teknologi budidaya tiram belum dilakukan secara detail oleh para peneliti di Aceh maupun di Indonesia. Oleh sebab itu, penulis ingin melakukan penelitian tentang teknik budidaya tiram dengan metode gantung, rak, dan didasar tanah yang bertujuan untuk melihat status perkembangan tiram pada setiap metode yang diujikan.

\section{Bahan dan metode}

\subsection{Waktu dan tempat}

Penelitian ini dilaksanakan pada tanggal 7 Juni - 31 Agustus 2015. Adapun lokasi penelitian adalah di Keramba Jaring Apung Loskala Lhokseumawe dan di Laboratorium Hatchery dan Teknologi Reulet Program Studi Budidaya Perairan Fakultas Pertanian Universitas Malikussaleh.

\subsection{Bahan dan alat}

Bahan dan alat yang digunakan dalam penelitian ini dapat dilihat pada Tabel 1 berikut:

Tabel 1.

Bahan dan alat yang digunakan dalam penelitian.

\begin{tabular}{llc}
\hline No. & \multicolumn{1}{c}{ Bahan dan alat } & Keterangan \\
\hline 1. & Termometer & Alat mengukur suhu \\
2. & DO Meter & Alat mengukur oksigen terlarut \\
3. & Refraktometer & Alat mengukur salinitas \\
4. & pH Meter & Alat Mengukur pH \\
5. & Timbangan Analitik & Untuk menimbang tiram \\
6. & Vernier Califer & Alat mengukur tiram \\
7. & Planktonet & Alat mengukur kepadatan fitoplankton \\
8. & Tali & Untuk mengikat peralatan wadah penelitian \\
9. & Keranjang & Wadah penelitian \\
10. & Jaring & Untuk menutup wadah penelitian \\
11. & Kayu & Bahan penelitian \\
12. & Tiram & Bahan uji \\
\hline
\end{tabular}

\subsection{Metode dan rancangan penelitian}

Metode penelitian yang digunakan adalah metode eksperimen dengan menggunakan metode pembesaran yang berbeda-beda. Hasil dari pengamatan dilakukan analisis secara statistik serta akan disajikan dalam bentuk tabel, grafik dan dijelaskan secara deskriptif.

Rancangan penelitian yang digunakan adalah Rancangan Acak Lengkap (RAL) dengan 3 perlakuan 3 ulangan. Perlakuan yang digunakan sebagai berikut:

Perlakuan A: Metode peletakkan benih tiram secara rak (horizontal)

Perlakuan B : Metode peletakkan benih tiram secara gantung (vertikal)

Perlakuan C: Metode peletakkan benih tiram didasar perairan dengan substrat batuan.

\subsubsection{Penyiapan wadah}

Wadah yang digunakan pada penelitian ini adalah wadah yang dibuat sendiri. Bahan-bahan yang dibutuhkan seperti bambu, tali, jaring, kayu. Wadah untuk metode gantung yaitu tiramnya dimasukkan ke dalam jaring dengan posisi tegak (vertikal) kemudian diikat atasnya selanjutnya di gantungkan pada tali dengan panjang 4 meter. Jarak masing-masing antara gantungan tiram tersebut dengan tiram yang lain adalah $10 \mathrm{~cm}$ setelah itu baru digantungkan di atas kayu keramba jaring apung. Metode gantung dapat dilihat pada Gambar 1.

Wadah metode rak yaitu berupa keranjang yang berukuran $45 \times 30 \times 15 \mathrm{~cm}$ sebanyak 3 keranjang kemudian tiram disusun memanjang dan di bawahnya diikat dengan tali untuk penempelannya. Metode rak dapat dilihat pada Gambar 2.

Wadah metode di dasar tanah yaitu di buat sepert lingkaran dan di letakkan bebatuan untuk substrat tiram. Pembatasnya terbuat dari papan benih tiram ini di letakkan langsung di dasar tanah dengan batu-batu tersebut sepert habitatnya di alam. Metode didasar tanah dapat dilihat pada Gambar 3.

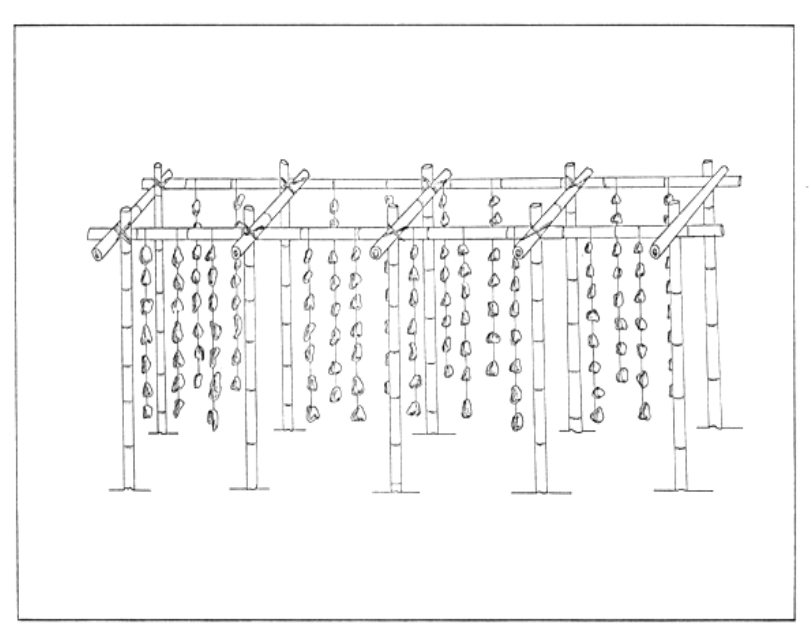

Gambar 1. Metode Gantung (Sumber : Kastoro, 1988) 


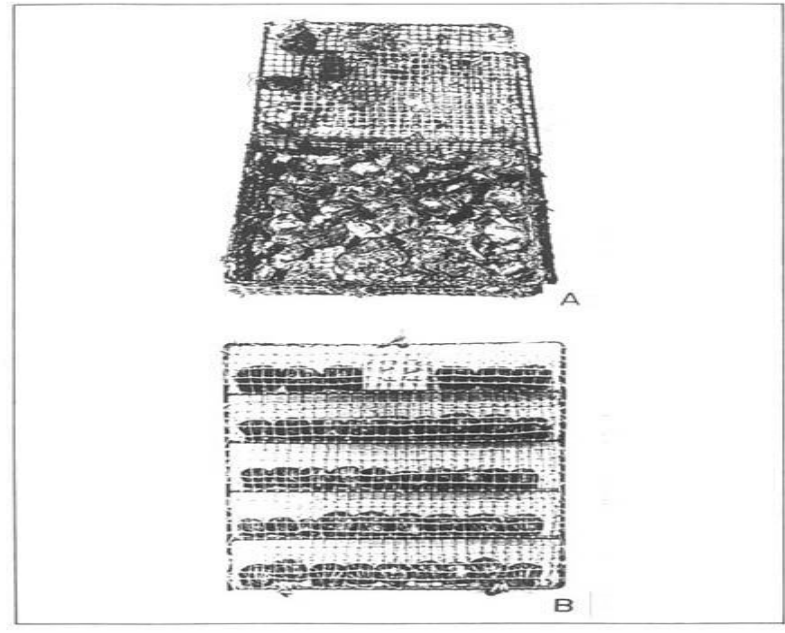

Gambar 2. Metode rak (Sumber : Kastoro, 1988)

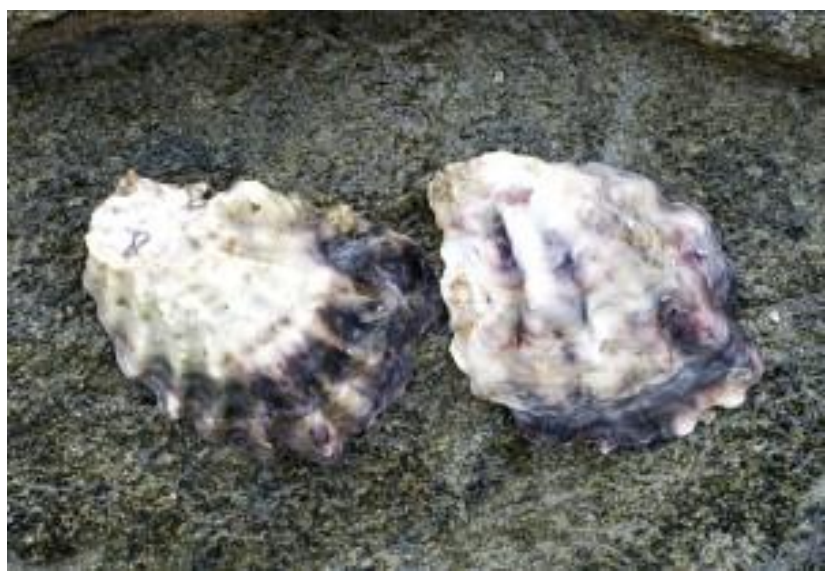

Gambar 3. Metode peletakan di subtrak batuan

\subsubsection{Introduksi tiram ke media perlakuan}

Tiram uji yang digunakan dalam penelitian ini adalah benih tiram yang diperoleh dari Loskala. Benih dimasukkan ke dalam wadah penelitian dengan kepadatan 15 ekor perwadah, ukuran benih yang digunakan 30-50 $\mathrm{mm}$. Cara meletakkannya pada substrat tersebut adalah spat-spat tiram di masukkan kedalam petakan rak kemudian ditutup dan rak tersebut digantungkan ke dalam air. Begitu juga tiram dengan metode gantung, tiramnya dimasukkan ke dalam jaring kemudian diikat atasnya dan setelah itu disambungkan lagi pada tali kemudian baru digantung pada kayu keramba. Kemudian di dasar tanah di letakkan bebatuan untuk substrat tiram dan dibuat pembatasnya agar batu-batu tersebut tidak terbawa oleh arus.

\subsection{Parameter uji}

Parameter uji yang diamati dalam penelitian ini adalah sebagai berikut:

\subsubsection{Pertumbuhan bobot}

Pertumbuhan bobot tiram diukur dari awal penelitian dan akhir penelitian. Pertumbuhan bobot diukur dengan menimbang tiram beserta cangkangnya menggunakan timbangan analitik.

\subsubsection{Pertambahan panjang dan pertambahan lebar cangkang tiram}

Pertambahan panjang dan lebar cangkang diukur setiap 10 hari sekali kepada seluruh spat tiram dengan menggunakan vernier califer. Jenis pertambahan yang diukur meliputi: panjang, lebar, dan ketebalan cangkang. Pengukuran panjang cangkang tiram dan lebar nya dapat dilihat pada Gambar 4. Rumus pengukuran panjang menurut Effendie (1979) yaitu:

$$
P=P t-P o
$$

Keterangan:

$P$ : Pertumbuhan panjang

Pt : Panjang rata-rata spat tiram pada hari ke $t(\mathrm{~cm})$

Po : Panjang rata-rata spat tiram pada hari ke $0(\mathrm{~cm})$

a).

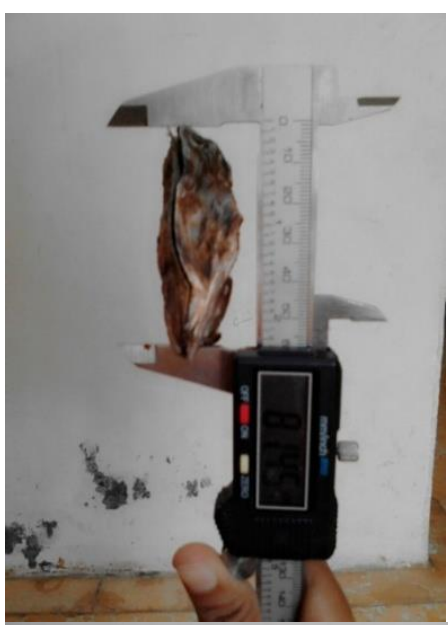

b).

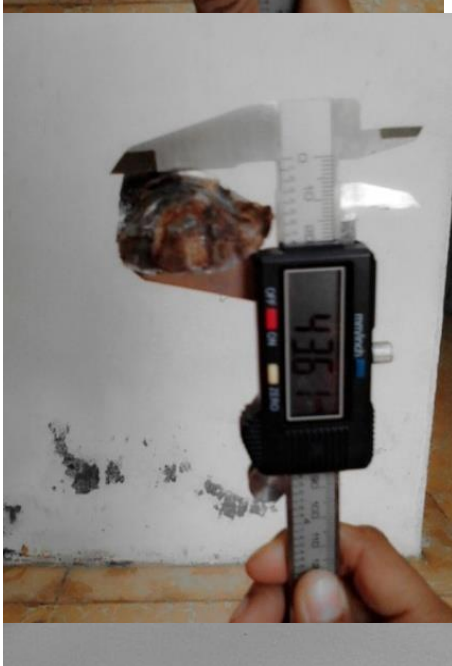

c).

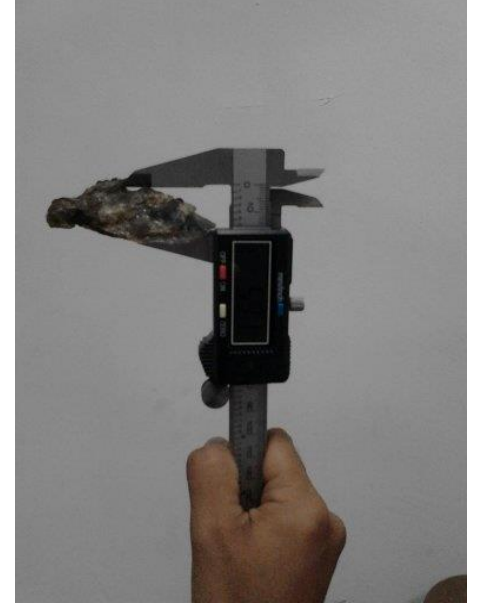

Gambar 4. Pengukuran panjang dan lebar cangkang tiram. a). Panjang tiram b). Lebar tiram c). Ketebalan cangkang 


\subsubsection{Kelangsungan hidup}

Pengamatan jumlah spat tiram yang hidup dilakukan pada awal dan akhir penelitian dengan cara menghitung seluruh jumlah spat yang masih hidup yaitu dengan menggunakan rumus Effendi (1979):

$$
\mathrm{SR}=\frac{\mathrm{Nt}}{\mathrm{No}} \times 100 \%
$$

Keterangan:

SR : Tingkat kelangsungan hidup (\%)

$\mathrm{Nt}$ : Jumlah tiram yang hidup pada akhir penelitian (ekor)

No: Jumlah tiram yang hidup pada awal penelitian (ekor)

\subsection{Kualitas air}

Pengukuran kualitas air dilakukan tiga hari sekali. Alat yang digunakan untuk mengukur parameter air adalah $\mathrm{pH}$ meter untuk mengukur $\mathrm{pH}$, termometer untuk mengukur suhu, DO meter untuk mengukur oksigen terlarut, refraktometer untuk mengukur salinitas, dan planktonet untuk mengukur kepadatan fitoplankton. Rumus kelimpahan plankton yang akan digunakan adalah (Fachrul, 2007).

$$
\mathrm{N}=\mathrm{n} \times(\mathrm{Vr} / \mathrm{Vo}) \times(1 / \mathrm{Vs})
$$

Keterangan :

$\mathrm{N}=$ Jumlah sel per liter

$\mathrm{n}=$ Jumlah sel yang diperhatikan

$\mathrm{Vr}=$ Volume air yang tersaring

Vo $=$ Volume air yang diperhatikan (pada Sedwidck Rafter)

$V_{s}=$ Volume air yang disaring

\subsection{Analisis Data}

Model umum rancangan yang digunakan menurut Gomez dan Gomez (1995), sebagai berikut:

$$
Y i j=\mu+\alpha i+\varepsilon i j
$$

Keterangan:

Yij : Nilai pengamatan pada perlakuan ke-i dan ulangan ke-j

$\mu$ : Rataan umum

ai : Pengaruh rataan ke-i

$\varepsilon i j$ : Pengaruh galat perlakuan ke-K pada ulangan ke-i

Data yang diperoleh dari pengamatan akan disajikan dalam bentuk tabel dan grafik, kemudian dianalisa dengan uji $F$ (Anova). Apabila F hitung $>\mathrm{F}$ tabel (berbeda nyata), selanjutnya dilakukan uji lanjut dengan menggunakan Uji BNT (Beda Nyata Terkecil).

\section{Hasil dan pembahasan}

\subsection{Hasil}

\subsubsection{Tingkat kelangsungan hidup}

Hasil pengamatan selama 80 hari menunjukkan bahwa desain tata letak yang berbeda sangat berpengaruh terhadap tingkat kelangsungan hidup tiram. Rata-rata tingkat kelangsungan hidup (SR) tiram di kawasan Loskala menunjukkan hasil kelangsungan hidup yang berbeda pada tiap perlakuan (Gambar 5). Adapun tingkat persentase kelangsungan hidup yang tertinggi terdapat pada perlakuan A dan B yaitu sebesar $84 \%$ dan yang paling terendah terdapat pada perlakuan C yaitu 0\% (semua mengalami kematian)

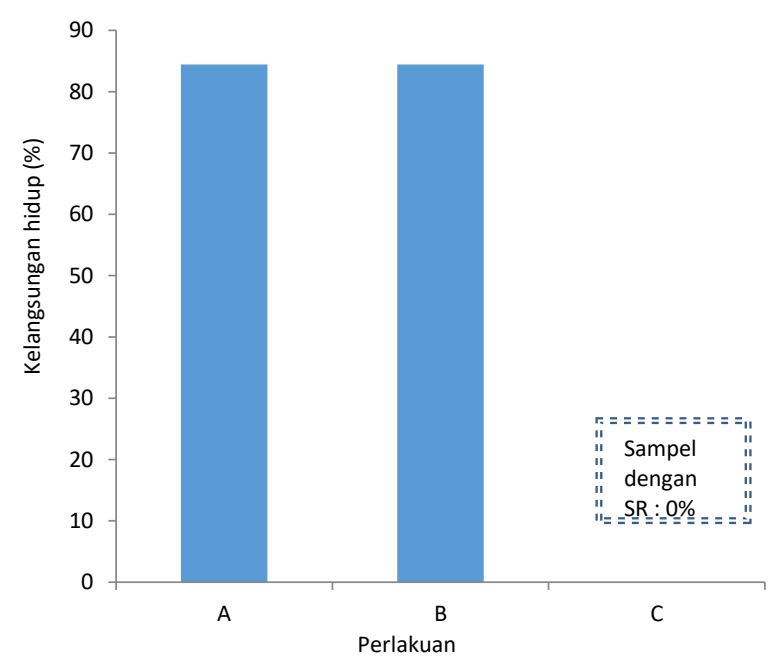

Gambar 5. Rata-rata kelangsungan hidup tiram (Crassostrea sp)

Keterangan:

$A=$ Metode peletakkan benih tiram secara rak (horizontal)

$\mathrm{B}=$ Metode peletakkan benih tiram secara gantung (vertikal)

$\mathrm{C}=$ Metode peletakkan benih tiram didasar perairan dengan substrat batuan

Berdasarkan analisis statistik dengan uji $\mathrm{F}$ menunjukkan bahwa pembesaran tiram (Crassostrea sp) di kawasan Loskala melalui desain tata letak yang berbeda menunjukkan hasil berpengaruh sangat nyata terhadap kelangsungan hidup tiram, dengan nilai Fhitung $(113)>$ Ftabel $(0,01)$. Dari hasil uji lanjut (BNT) memperoleh hasil bahwa pada perlakuan yang berbeda nyata terdapat antar perlakuan $B$ dengan $C$ dan perlakuan $A$ dengan $\mathrm{C}$.

\subsubsection{Pertumbuhan bobot dan panjang tiram}

Pembesaran tiram (Crassostrea $\mathrm{sp}$ ) di kawasan Loskala dengan desain tata letak yang berbeda menunjukkan hasil yang berbeda terhadap pertambahan bobot tiram. Adapun rata-rata peningkatan pertambahan bobot tiram pada berat awal dan berat akhir untuk masing-masing perlakuan dapat dilihat pada Gambar 6.

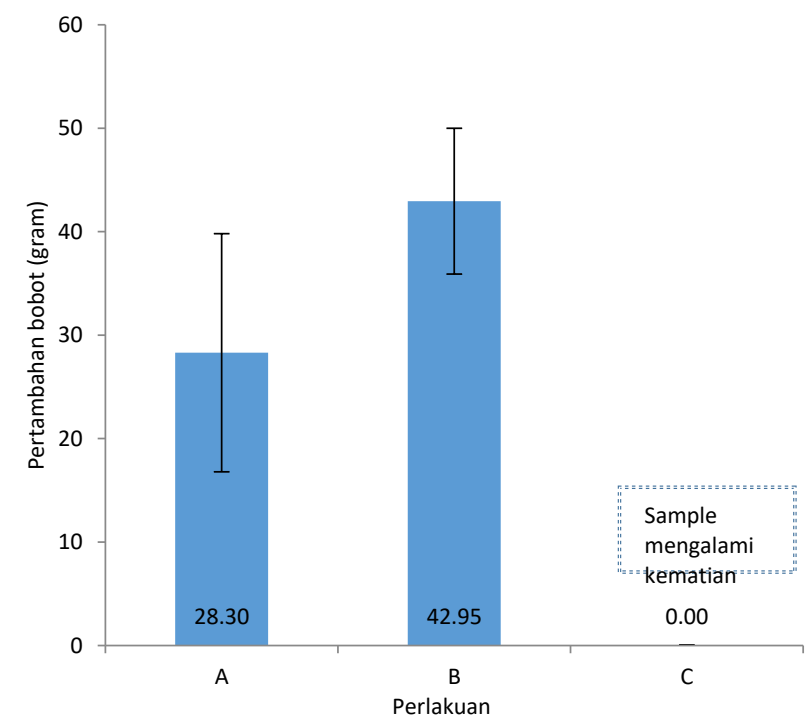

Gambar 6. Rata-rata pertambahan bobot tiram (Crassostrea sp) Keterangan:

$\mathrm{A}=$ Metode peletakkan benih tiram secara rak (horizontal)

$B=$ Metode peletakkan benih tiram secara gantung (vertikal)

$\mathrm{C}=$ Metode peletakkan benih tiram didasar perairan dengan substrat batuan 
Rata-rata pertambahan bobot tiram yang tertinggi terdapat pada perlakuan B yaitu 42,95 gram. Selanjutnya pada perlakuan A yaitu 28,30 gram. Kemudian rata-rata pertambahan bobot yang terendah terdapat pada perlakuan $C$ yaitu 0,00 gram (semua mengalami kematian).

Berdasarkan analisis statistik dengan uji $\mathrm{F}$ menunjukkan bahwa pembesaran tiram (Crassostrea sp) di kawasan Loskala dengan desain tata letak yang berbeda (secara gantung/vertikal, secara rak/horizontal, dan didasar perairan/substrat batuan) menunjukkan hasil berpengaruh sangat nyata terhadap pertambahan bobot tiram (Crassostrea $\mathrm{sp}$ ) dengan nilai Fhitung (24) > Ftabel $(0,01)$. Dari hasil uji lanjut (BNT) memperoleh hasil bahwa pada setiap perlakuan yang berbeda nyata terdapat antar perlakuan $B$ dengan $C$ dan $A$ dengan $C$. selanjutnya pembesaran tiram (Crassostrea sp) di kawasan Loskala dengan desain tata letak yang berbeda menunjukkan hasil rata-rata pertambahan panjang tiram untuk masing-masing perlakuan dapat dilihat pada Gambar 7.

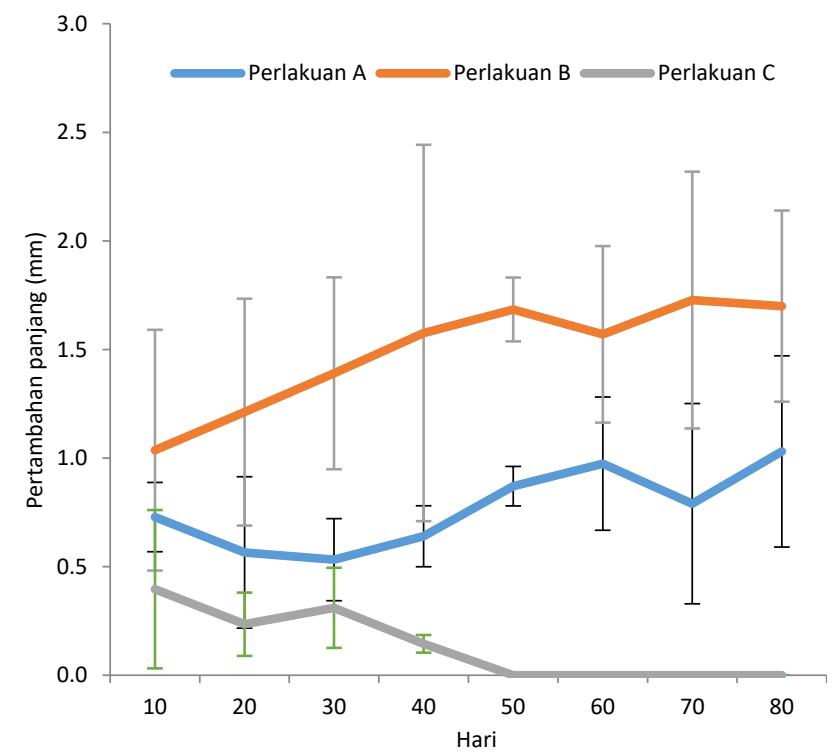

Gambar 7. Rata-rata pertambahan panjang tiram (Crassostrea sp) Keterangan:

$A=$ Metode peletakkan benih tiram secara rak (horizontal)

$\mathrm{B}=$ Metode peletakkan benih tiram secara gantung (vertikal)

$\mathrm{C}=$ Metode peletakkan benih tiram didasar perairan dengan substrat batuan

Rata-rata pertambahan panjang tiram yang tertinggi terdapat pada perlakuan B yaitu sebesar 1,487 mm. Kemudian pertambahan panjang perlakuan $A$ yaitu sebesar $0,766 \mathrm{~mm}$, sedangkan pertambahan panjang yang terendah terdapat pada perlakuan $C$ yaitu sebesar $0,00 \mathrm{~mm}$ (mengalami kematian).

Berdasarkan analisis Statistik dengan uji $F$ bahwa pembesaran tiram (Crassostrea $\mathrm{sp}$ ) di kawasan Loskala dengan desain tata letak yang berbeda, menunjukkan hasil berpengaruh sangat nyata terhadap pertambahan panjang tiram dengan nilai Fhitung (635) > Ftabel $(0,01)$. Kemudian dari hasil uji BNT (Beda Nyata Terkecil) diperoleh hasil bahwa pada setiap perlakuan berbeda antar perlakuan dan pertambahan panjang yang terbaik juga terdapat pada perlakuan B.

Pembesaran tiram (Crassostrea sp) di kawasan Loskala dengan desain tata letak yang berbeda menunjukkan hasil yang berpengaruh terhadap pertambahan lebar tiram. Adapun ratarata pertambahan lebar tiram setiap sepuluh hari untuk masingmasing perlakuan dapat dilihat pada Gambar 8.

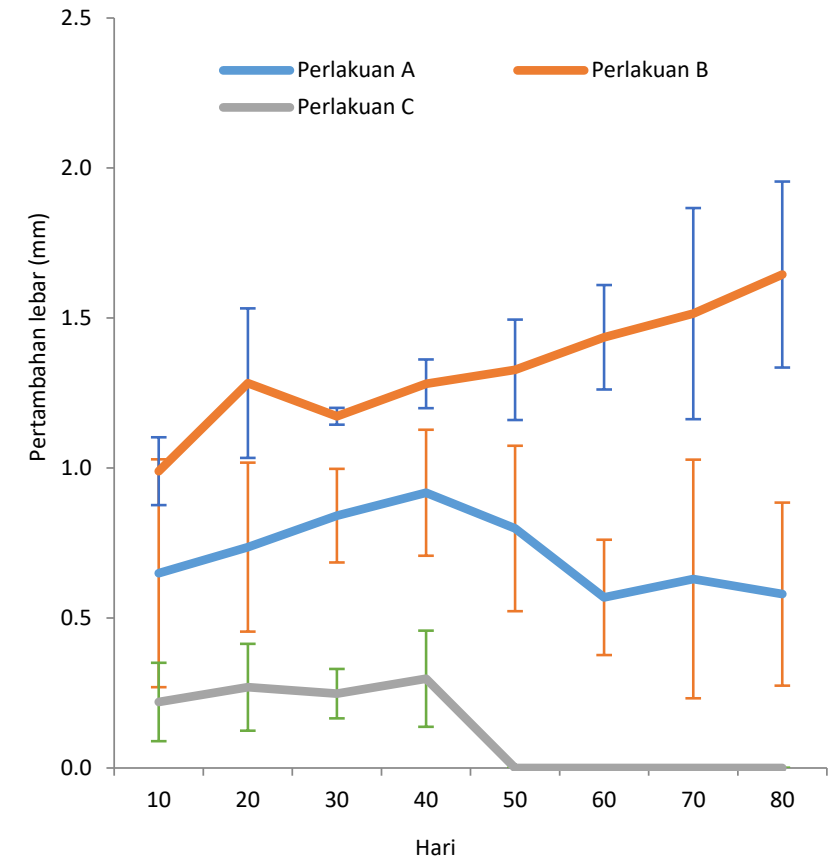

Gambar 8. Rata-rata pertambahan lebar tiram (Crassostrea sp)

Keterangan:

$A=$ Metode peletakkan benih tiram secara rak (horizontal)

$\mathrm{B}=$ Metode peletakkan benih tiram secara gantung (vertikal)

$\mathrm{C}=$ Metode peletakkan benih tiram didasar perairan dengan substrat batuan

Rata-rata pertambahan lebar tiram yang tertingg terdapat pada perlakuan B yaitu sebesar $1,331 \mathrm{~mm}$. Selanjutnya pertambahan lebar pada perlakuan $A$ yaitu sebesar $0,715 \mathrm{~mm}$ dan pertambahan lebar tiram yang terendah terdapat pada perlakuan $C$ yaitu $0,00 \mathrm{~mm}$.

Berdasarkan analisis statistik dengan uji $\mathrm{F}$ menunjukkan bahwa pembesaran tiram (Crassostrea sp) di kawasan Loskala dengan desain tata letak yang berbeda, menunjukkan hasil berpengaruh sangat nyata terhadap pertambahan lebar tiram dengan nila Fhitung $(2383)>$ Ftabel $(0,01)$. Dari hasil uji lanjut (BNT) diperoleh hasil bahwa pada setiap perlakuan yang berbeda nyata terdapat antar perlakuan B dengan A dan C, perlakuan A dengan $\mathrm{C}$.

Rata-rata pertambahan ketebalan cangkang tiram setiap sepuluh hari untuk masing-masing perlakuan dapat dilihat pada Gambar 9. Rata-rata pertambahan ketebalan cangkang tiram yang tertinggi terdapat pada perlakuan B yaitu sebesar 1,843 $\mathrm{mm}$. Selanjutnya pada perlakuan A dengan ketebalan cangkang sebesar 1,187 $\mathrm{mm}$ dan pertambahan ketebalan cangkang yang terendah terdapat pada perlakuan $\mathrm{C}$ yaitu $0,00 \mathrm{~mm}$.

Berdasarkan analisis statistik dengan uji $F$ bahwa pembesaran tiram (Crassostrea sp) di kawasan Loskala dengan desain tata letak yang berbeda menunjukkan hasil berpengaruh sangat nyata terhadap pertambahan ketebalan cangkang tiram dengan nilai Fhitung (1167) Ftabel $(0,01)$. Dari hasil uji lanjut (BNT) diperoleh hasil bahwa pada setiap perlakuan berbeda antar perlakuan dan pertambahan ketebalan cangkang terbaik juga terdapat pada perlakuan B. 


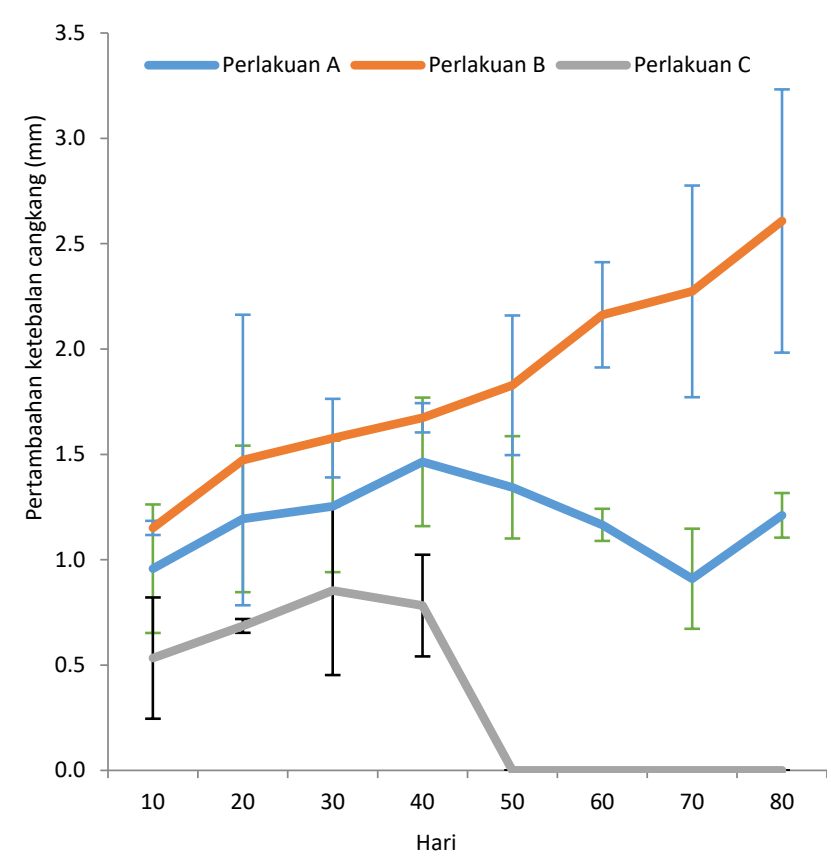

Gambar 9. Rata-rata pertambahan ketebalan cangkang tiram (Crassostrea sp) Keterangan:

$A=$ Metode peletakkan benih tiram secara rak (horizontal)

$\mathrm{B}=$ Metode peletakkan benih tiram secara gantung (vertikal)

$\mathrm{C}=$ Metode peletakkan benih tiram didasar perairan dengan substrat batuan

\subsubsection{Kualitas air media}

Kualitas air yang baik akan membantu proses pertumbuhan tiram (Crassostrea $\mathrm{sp}$ ). Parameter fisika kimia air yang diamati dalam penelitian ini selama 80 hari adalah suhu, $\mathrm{pH}$, DO dan salinitas. Berdasarkan hasil penelitian menunjukkan bahwa kualitas air selama penelitian kondisinya berada pada kisaran yang sesuai untuk pertumbuhan tiram. Hasil pengamatan kisaran perubahan kualitas air selama penelitian dapat dilihat pada Tabel 2.

Tabel 2.

Data kualitas air selama penelitian

\begin{tabular}{clccc}
\hline No. & Parameter & Hasil Pengamatan & Rata-rata & Standar Deviasi \\
\hline 1 & Suhu & $27-30^{\circ} \mathrm{C}$ & $28,5^{\circ} \mathrm{C}$ & 0,63 \\
2 & $\mathrm{pH}$ & $6,8-7,5$ & 7,31 & 0,2 \\
3 & DO & $4,8-7,4 \mathrm{ppm}$ & $5,75 \mathrm{ppm}$ & 0,68 \\
4 & Salinitas & $30-35 \mathrm{ppt}$ & $32,5 \mathrm{ppt}$ & 1,43 \\
\hline
\end{tabular}

Adapun kelimpahan fitoplankton di perairan Loskala yang telah diamati pada bulan pertama penelitian terdapat jumlah fitoplankton sebanyak $7835,8 \mathrm{sel} / \mathrm{I}$ sedangkan pada bulan ke dua penelitian terdapat jumlah fitoplankton sebanyak 9807,7 $\mathrm{sel} / \mathrm{L}$.

\subsection{Pembahasan}

\subsubsection{Hubungan tata letak dengan kelangsungan hidup tiram}

Tinggi dan rendahnya rata-rata nilai kelangsungan hidup tiram ini disebabkan karena ketersedian pakan sesuai dengan kebutuhannya. Kehidupan sesuai dengan habitat aslinya dan kualitas air pada saat penelitian dalam keadaan yang baik untuk pertumbuhan tiram. Habitat sangat mempengaruhi pertumbuhan tiram karena sifat hidupnya cenderung menempel pada substrat. Tata letak yang berbeda sangat berpengaruh terhadap kelangsungan hidup tiram dikarenakan faktor ketersediaan makanan dan faktor lingkungan. Ini sesuai dengan pendapat Dame (1996), yang menyatakan bahwa faktor ketersediaan makanan (fitoplankton, zooplankton, zat organik tersuspensi) dan habitat ikut berpengaruh dalam menunjang kelangsungan hidup serta pertumbuhan bivalvia. Dengan tata letak secara horizontal dan vertikal tidak menghambat tiram dalam penyaringan makanan. Bivalvia mendapatkan makanan dengan filtrasi menggunakan siphon demi menghindari kompetisi makanan sesama spesies (Nurdin et al., 2008). Dalam upaya mempertahankan kelangsungan hidupnya, makhluk hidup berinteraksi dengan lingkungan dan cenderung untuk memilih kondisi lingkungan serta tipe habitat yang terbaik untuk tetap tumbuh dan berkembangbiak.

Tingkat persentase kelangsungan hidup yang tertinggi terdapat pada perlakuan A dan B ini disebabkan bahwa tata letak tiram secara rak dan gantung tidak mempengaruhi terhadap kelangsungan hidup karena tata letak tersebut tidak menghambat suplai makanan, tidak adanya persaingan makanan antar tiram lainnya, dan tidak terjadinya pengendapan partikelpartikel. Menurut Jorgensen (1990), menyatakan bahwa tiram memiliki kemampuan untuk memompa partikel tersuspensi dengan menggunakan insangnya. Pada saat memompa, cangkang akan terbuka lebar dan mantel memanjang sehingga akan menghasilkan tekanan dan arus air. Partikel tersuspensi yang dibutuhkan, fitoplankton dan bahan organik, akan masuk ke dalam mulut kemudian partikel yang tidak dibutuhkan akan diubah menjadi pseudofaeces kemudian dibuang.

Perlakuan C semua tiram mengalami kematian ini disebabkan peletakkan tiram di dasar perairan pada substrat batuan, dimana suplai makanan terbatas. Menurut Gosling (2003), pertumbuhan pada bivalvia dipengaruhi oleh banyak faktor, dan faktor yang paling penting yaitu suplai makanan. Tanpa adanya suplai makanan maka tidak akan terjadi proses pertumbuhan yang baik. Penyebab kematian bisa dikarenakan arus perairan Loskala dimana daya perekat tiram dibatuan tidak maksimal maka terbawa arus. Sesuai dengan pendapat Sutaman (1993) menyatakan bahwa faktor lingkungan yang berpengaruh terhadap lokasi potensi tiram yaitu dasar perairan, kedalaman, arus air, salinitas, suhu, kecerahan, oksigen terlarut dan $\mathrm{pH}$. Salah satu indikasi yang menunjukkan tidak cocoknya suatu habitat bagi biota adalah rendahnya kelimpahan biota tersebut pada suatu area ataupun ketidakmampuannya berdistribusi mencapai area tersebut.

\subsubsection{Hubungan tata letak dengan pertumbuhan tiram}

Perlakuan B (secara gantung/vertikal) menunjukkan hasil rata-rata yang tertinggi pada pertambahan bobot yaitu sebesar 92,04 gram. Ini disebabkan pada perlakuan B tata letak tiram dilakukan secara gantung tidak terjadi persaingan makanan dengan tiram yang lain. Kemudian letak tiram secara gantung pada pertengahan perairan Loskala memudahkan tiram memanfaatkan makanan secara langsung berupa fitoplankton yang terbawa arus, karena arus sangat berpengaruh terhadap suplai makanan.

Hal ini sesuai dengan pendapat Romimohtarto (2003) manfaat dari arus adalah menyuplai makanan, kelarutan oksigen, penyebaran plankton dan penghilangan $\mathrm{CO} 2$ maupun sisa-sisa produk biota laut. Semakin banyak suplai makanan diperairan maka semakin cepat pertumbuhan. Menurut Gosling (2003), meskipun di alam bivalvia memakan bermacam-macam jenis partikel tersuspensi seperti bakteri, fitoplankton, microzooplankton, detritus dan bahan organik terlarut, akan tetapi fitoplankton merupakan sumber makanan yang paling digemari.

Keberadaan fitoplankton sangat penting bagi kehidupan tiram ini disebabkan fitoplankton memegang peran penting sebagai makanan bagi tiram dan organisme laut lainnya. Ini 
sesuai dengan pendapat Fathurrahman dan Aururohim (2014) yang menyatakan bahwa keberadaan fitoplankton sangat berpengaruh terhadap kehidupan di perairan karena memegang peran penting sebagai makanan bagi berbagai organisme laut. Keberadaan fitoplankton dijadikan indikator kesuburan suatu perairan.

Pertambahan panjang, lebar dan ketebalan cangkang tiram (Crassostrea sp) spesifik yang paling tinggi terdapat pada perlakuan $B$ dengan nilai panjang rata-rata yaitu $1,487 \mathrm{~mm}$, nilai lebar rata-rata yaitu $1,331 \mathrm{~mm}$, dan nilai ketebalan cangkang rata-rata yaitu $1,843 \mathrm{~mm}$. Ini diduga bahwa tata letak tiram secara gantung sangat mempengaruhi pertumbuhan tiram, karena pakan berupa fitoplankton yang terbawa arus dimanfaatkan secara langsung tanpa adanya persaingan dan pemanfaatan lebih stabil tidak terbawa arus. Kemudian perairan Loskala memiliki kecepatan arus yang sesuai dengan habitat tiram. Sudjiharno et al. (2001) menyatakan bahwa kecepatan arus berperan penting dalam keberhasilan suatu kegiatan budidaya baik pada sirkulasi air dan pengangkutan unsur hara.

Pertambahan bobot yang terendah terdapat pada perlakuan $C$ yaitu 0,00 gram (semua mengalami kematian). Ini disebabkan karena letak tiram didasar perairan/substrat batuan sangat berpengaruh terhadap kehidupan tiram karena didasar perairan sedikitnya suplai makanan seperti fitoplankton yang mengakibatkan terjadinya persaingan sesama tiram dan lainnya, kemudian pelan nya arus didasar perairan menyebabkan terjadinya penumpukan partikel-partikel atau sedimen yang terlalu banyak di atas tiram sehingga tiram tidak bisa lagi menyaring makanan yang akhirnya menyebabkan kematian.

Hal ini juga terbukti hasil dari ketebalan cangkang yang terdapat pada perlakuan B yaitu sebesar 1,843 mm lebih besar dari pada perlakuan lainnya dan begitu juga dengan isi daging tiram. Kemudian pada perairan Loskala terdapat kelimpahan fitoplankton yang banyak dan tidak terjadinya kekurangan makanan, karena kelimpahan plankton disuatu perairan sangat mempengaruhi pertumbuhan tiram (Crassostrea sp). Ini sesuai dengan pendapat Fathurrahman dan Aunurohim (2014) menyatakan bahwa untuk kepentingan budidaya keberadaan fitoplankton sangat dibutuhkan di perairan sebagai makanan biota laut yang dibudidayakan. Untuk menentukan lokasi budidaya yang ideal salah satunya dengan melihat kelimpahan dan komposisi fitoplankton di perairan tersebut.

\subsubsection{Kualitas air dan pertumbuhan tiram}

Hasil pengukuran kualitas air selama penelitian di Loskala sangat mendukung untuk budidaya tiram (Crassostrea sp). Adapun kisaran kualitas air selam penelitian adalah suhu (27-30 $\left.{ }^{\circ} \mathrm{C}\right)$, pH $(6,8-7,5)$, DO $(4,8-7,4 \mathrm{ppm})$, dan salinitas (30-35 ppt). menurut Utojo et al. (2005) bahwa pertumbuhan dan kelangsungan hidup tiram (Crassostrea sp) berlangsung baik pada suhu berkisar antara $15-33^{\circ} \mathrm{C}$, salinitas berkisar antara 15$35 \mathrm{ppt}$, oksigen terlarut (DO) berkisar antara 3-6 ppm dan pH berkisar antara 6-8. Tinggi rendahnya parameter kualitas air dipengaruhi oleh suhu, apabila suhu mengalami peningkatan maka yang lain juga akan ikut naik.

Berdasarkan hasil penelitian dapat disimpulkan bahwa parameter kualitas air pada saat penelitian masih dalam batas kisaran kualitas air yang normal untuk kelangsungan hidup tiram (Crassostrea sp).

\section{Kesimpulan}

Desain tata letak yang berbeda berpengaruh sangat nyata terhadap pertambahan panjang, bobot, lebar dan ketebalan cangkang tiram serta kelangsungan hidup tiram (Crassostrea sp). Rata-rata tingkat kelangsungan hidup yang tinggi terdapat pada perlakuan A dan B yaitu $84 \%$. Pertambahan bobot, panjang, lebar dan ketebalan cangkang tiram terbaik terdapat pada perlakuan B (secara gantung/vertikal). Kualitas air selama penelitian suhu $27-30{ }^{\circ} \mathrm{C}, \mathrm{pH} 6,8-7,5$, DO 4,8-7,4 ppm dan salinitas 30-35 ppt.

\section{Bibliografi}

Aunurohim, A., Fathurrahman, F., 2014. Kajian Komposisi Fitoplankton dan Hubungannya dengan Lokasi Budidaya Kerang Mutiara (Pinctada maxima) diperairan Sekotong, Nusa Tenggara Barat. Surabaya: Jurusan Biologi, Fakultas Matematika dan IImu Pengetahuan Alam, Institut Teknologi Sepuluh November (ITS).

Dame, R. F., 1996. Ecology of marine bivalvia and ecosystem approach. CRC Press. NewYork, 240p.

Effendie, M. I., 1979. Metode Biologi Perikanan. Bogor: Yayasan Dwi Sri.

Gomez, K. D., Gomez, K. D., 1995. Prosedur Statistik Untuk Penelitian Pertanian. Jakarta: Universitas Indonesia.

Gosling, E., 2003. Bivalve Molluscs: Biology, Ekology and Culture. Fishing New Books, UK. 443 pp.

Jorgensen, C. B., 1990. Bivalve Filter Feeding: Hydrodynamics Bioenergetics, Physiology and Ecology. Olsen \& Olsen. Denmark , 136 pp.

Kastoro, W., 1988. Budidaya Jenis-Jenis Kerang (Bivalvia). Semarang: Laboratorium Pengembangan Wilayah Pantai, Universitas Diponegoro.

Meglitsch, P. A., 1972. Invertebrata Zoology. London: Oxford University Press.

Nurdin, J., Supriatna J., Patria, M.P., Budiman, A., 2008. Kepadatan dan keaneragaman Kerang Intertidal (Mollusca: Bivalves) Diperairan Pantai Sumatera Barat. Prosiding seminar nasional Sains dan Teknologi- II Universitas Lampung, 17-18 November 2008 , 505-519.

Romimohtarto, K., 2003. Kualitas Air Dalam Budidaya Laut (Online). Retrieved 2 24, 2015, from www.fao.org/docrep/field/003.

Sudjiharno, Meiyana, M., Akbar, S.,. (2001). Pemanfaatan Teknologi Rumput laut dalam Rangka Intensifikasi Pembudidaya. Lampung: Bulleti Budidaya Laut. DKP. Balai Budidaya Laut.

Sutaman. (1993). Teknik Budidaya Mutiara. Yogyakarta: Penerbit Kanisius.

Umaryati, B. S. (1990). Taksonomi Avertebrata. Jakarta: Cetaka Permata. Penerbit Universitas Indonesia Press. 
Acta Aquatica, 3:2 (Oktober, 2016): 54-61

Utojo, Mansyur, A., Pirzan, A.M., Tarunamulia, Pantjara, B., 2005. Identifikasi Kelayakan Lokasi Budidaya Laut di Perairan

Teluk Kupang, Nusa Tenggara Timur. Journal Penelitian Perikanan Indonesia. 5(10). 